\title{
Translator's Preface
}

Marcos Iolovitch, author of On a Clear April Morning, was an avid student of the great philosophers. But he believed that to reach "true wisdom" we need to open our windows and observe the "subtle shades of reality that envelope" us. ${ }^{1}$ In this autobiographical novel, in which a young man seeks to find a righteous and fulfilling path, we watch this charming and caring protagonist discover his own wisdom through the realities that envelop him, the realities of Jewish immigrants in southern Brazil during the first decades of the twentieth century.

As the readers of On a Clear April Morning will learn, this story of immigration to Brazil began as a dream for Marcos Iolovitch's father, Yossef, in Zagradowka, a small village one hundred and seventy miles northeast of Odessa in the southern Ukrainian province of Kherson. The publication of this work in English is the fulfillment of a dream that began for me nearly thirty years ago, in Porto Alegre, a small city in Southern Brazil (pop. 1.5 million), five hundred miles south of São Paulo. Porto Alegre, where I served as the public affairs officer in the US Consulate, is the capital of the state of Rio Grande do Sul, home of those that are affectionately called Gaúchos (Gau-oo-chos).

Rio Grande is strongly tied to its European roots as revealed in the faces, surnames, and cuisine alike. ${ }^{2}$ A land of immigrants, Germans, Jews, Arabs, Italians, Poles, Portuguese, Rio Grande "has created a . . p peaceful marriage of cultures." ${ }^{\prime 3}$ It is a place where, as Iolovitch relates, a youngster from a Yiddish speaking family could have as his best friend a son of German immigrants, a place where education could begin in a Jewish "cheder" and later be influenced by Jesuit teachers.

Here you won't find any of Brazil's famed beaches. But you will find, perched on hilltops with breathtaking sunsets over the Guaiba River, a city where civic life, education, and intellectual pursuits matter. 
In Porto Alegre, political engagement is a highly held value. It is the capital of a state with only seven percent of the national population, but a state that has given Brazil over twenty percent of its presidents.

Porto Alegre is home to two of Brazil's finest universities, both noted for their teaching and the quantity and excellence of their humanistic and scientific research: the Federal University of Rio Grande do Sul (UFRGS) and the Catholic University of Rio Grande do Sul (PUCRS), rated the best private university in the country. ${ }^{4}$

This translation of On a Clear April Morning is the result of the work of another Gaucho center of intellectual inquiry, The Marc Chagall Cultural Institute. ${ }^{5}$ Founded in 1985 by Jewish intellectuals and business people, many descendants of immigrants who followed the same path as the Iolovitch family, Instituto Cultural Marc Chagall seeks to preserve and disseminate all aspects of Jewish culture and history. In 1991 the Institute published Caminhos da esperanca/Pathways of Hope, ${ }^{6}$ a bilingual history of Jews in Rio Grande do Sul. It was written by the critically acclaimed Brazilian Jewish author, Moacyr Scliar, who the New York Times described as "one of Brazil's most celebrated novelists and shortstory writers". ' Moacyr asked me to edit the English text. He also gave me the chance to share his love for Iolovitch's novel, which had inspired his own body of work.

Caminhos da esperanca begins its historical essay with the beautiful opening lines of this novel, "On a clear April morning in the year 19when the steppes had begun to turn green again upon the joyful entrance of Spring, there appeared scattered about in Zagradowka, a small and cheerful Russian village in the province of Kherson, beautiful brochures with colored illustrations describing the excellent climate, the fertile land, the rich and varied fauna, and the beautiful and exuberant flora, of a vast and faraway country of America, named-BRASIL." And throughout Caminhos da esperanca Iolovitch's descriptive prose is cited.

I read On a Clear April Morning at one sitting. Delighted by the mixture of lyricism and history that Iolovitch gives us, I wanted the world to have this book. I promised myself that someday I would translate it and obtain its publication in English. That day has finally come.

On a Clear April Morning, first published in 1940, has been recognized by many as the first literary work to draw on the experiences of Russian Jewish immigrants in Brazil. But in the history of Brazilian literature it has an even more important place. As Regina Igel, Coordinator of the Portuguese Program at the University of Maryland, who has spent her life studying the Jewish component in Brazilian literature explains, On a 
Clear April Morning was "the first [Jewish] needle to penetrate the Brazilian literary fabric ... [and] was apparently the first novel in Portuguese that draws its subject matter from the Brazilian Jewish community."

As "an inaugural landmark in the [Brazilian] Jewish literary panorama," and as an historical document depicting the trajectory of early twentieth-century Jewish immigrants to Brazil, On a Clear April Morning is indeed worthy of respect. But it is Iolovitch's lyricism, his ability to paint a picture of the emotions and scenes he describes that makes readers fall in love with this book.

Iolovitch's enchanting opening lines that so captivated Scliar have been quoted time and again by those describing Brazilian Jewish or regional literature. But these are only the beginning. On a Clear April Morning is full of poetry and often the poetry has musical allusions. Just to cite a few instances: upon departing their Ukrainian village after all the goodbyes, Iolovitch's father's wagon moved down a lonely road as Marcos describes "Chimneys unfolded slow plumes of smoke in the chilly morning air. In concert, the cadence of a distant engine and the rhythmic fall of a hammer upon an anvil accompanied the slow ascent of the day...."

Or when he fell in love, Marcos laments the object of his heart that is many miles away: "Her image never left me, not for a second. I saw her in everything and everywhere. She was on the page of the book that I opened, on the blank sheets of paper that I touched, in the paleness of the moon, and in the brilliance of the stars."

Or when his poverty forces him to live in a leaky newspaper-lined shed, he communes with the "drops of water [that] began to beat to the rhythm of the rain....

Little droplet, little droplet, I murmured, how sad is your muffled tempo..., your sad cadence...."

On a Clear April Morning is full of poetry and musical cadences and tempos because Marcos Iolovitch was both a musician and a poet. He supported himself by teaching the violin for several years. And poetry was his real literary love. On a Clear April Morning is Iolovitch's only full-length narrative work. His two other books Eu e Tu (I and Thou) published in 1932 and Preces Profanas (Secular Prayers) published in 1949 are collections of poems and poetical aphorisms.

As do so many young poets, this sensitive young man used his pen to understand humanity and the meaning of life. As he describes, the first years in Brazil did not fulfill his father's dream. Instead they were full of hunger, tragic deaths, economic failures, anti-Semitism, and his father's alcoholic response. "Why and for what do we live?" Iolovitch asks. Why does God 
"distribute rewards and punishments without even the most basic concern for equality and justice"?

He seeks his answers in the great nineteenth- and early twentieth-century philosophers, in the realm of the intellect where one of his favorite philosophers, Arthur Schopenhauer, noted, " pain has no power." ${ }^{10}$ Iolovitch dedicates a whole chapter of On a Clear April Morning to Schopenhauer. And he most likely took the title of his first book, I and Thou from the bestknown treatise of the great Jewish philosopher, Martin Buber. In I and Thou, Iolovitch reflects the concept that Buber develops in his I and Thou that "man becomes whole not in relation to himself but only through relation to another self". ${ }^{11}$

In Buber the true I-Thou relationship is that "in which two persons face and accept each other as truly human." ${ }^{2}$ This acceptance of each person as truly human and the compassion that results is what defined Iolovitch. Moacyr Scliar describes him as "endowed with a charming kindness."13

Iolovitch was kind because he cared about others. Even when he was wronged, he saw his aggressors as human beings. Instead of becoming vengeful he tried to understand them. After being attacked by anti-Semitic bullies, for example, he realizes that their anger towards Jews was not an inherent evil. Rather it was the result of some priests who taught their students the most incredible lies about Jews. Instead of bringing to their students the commandment to "love thy neighbor as preached by Christ, they brought the seeds of hate...."

As a child Iolovitch's greatest pain came from "the tears of my mother and my two brothers..., " caused by his father's drinking. But even then, he understood that his father was a "good man [who drank because] it hurt him to see the family reduced to such a deplorable state." As he grows, Iolovitch's compassion reaches further. He dedicated On a Clear April Morning to "all those who suffer and dream of a better world."

In 1940 an interviewer wrote, "Marcos is a great idealist, a passionate dreamer that takes very seriously human existence and he is totally sincere when he says that his wish is for a better world for all humanity." ${ }^{14} \mathrm{He}$ was inspired by authors that "elevated mankind, that dignified the human species, that ennobled life." ${ }^{15}$ And that is what he attempted in On a Clear April Morning. He describes the nobility of his everyday characters, as in his brother's efforts to build a pushcart so they can peddle fish, or in an older couple's efforts to enliven the life of a young child from a poor family with trips to an unknown paradise, the movie house.

But after the Second World War and all its horrors Iolovitch becomes a very frustrated idealist. His final book, Preces Profanas (1949), is a protest 
to the Lord for the suffering of all mankind, "Jews, Catholics, the Muslims, and Buddhists, the believers and nonbelievers, the saints and the sinners."16

Like most literary works, On a Clear April Morning was not created in an intellectual vacuum. Since the 1890s Rio Grande do Sul had been Brazil's most literate state and by the 1920s Porto Alegre "already possessed ... important books stores, cinemas, newspapers and an active intellectual life ... [with] dozens of published authors." ${ }^{17}$ This city of immigrants was enriched by a European concern for ideas and enjoyed European resources. Often Germany was the source. ${ }^{18}$ Twenty percent of the state was Germanborn or descendants of German immigrants. Various bookstores sold works in German and German Jesuits were instrumental in supporting the study of philosophy in both Catholic and secular educational institutions, including those that Iolovitch and his friends attended. ${ }^{19}$

German most likely presented Marcos with few difficulties. Even early on Iolovitch's family, like probably many of the Jewish immigrants, had found comfort in Rio Grande's German roots. When a nurse of German descent needed to explain to Marco's father that the nine-year-old boy had typhoid fever, she had no problem. Yiddish, the language of Eastern European Jews, is descended from a medieval German dialect.

But most important for writers, Porto Alegre was the home of one of Brazil's most dynamic publishing houses, Editora Globo, and its noted literary journal, Revista do Globo.

Editora Globo sought the newest in literature and offered the chance to publish to many young writers. As a result, in the 1930s and 40s Rio Grande do Sul gave Brazil some of its most important authors. Each one "reached out to a different sector of reality seeking to convey it with his own personal vision." These authors often described "human beings whose living conditions were far from ideal," and often designed plots that addressed philosophical, political, and social issues. ${ }^{20}$ They had a cultural conscience. They were concerned with principles, with goodness and sought to balance intellectual and psychological concerns. ${ }^{21}$ And in some works, the lyricism was extreme..$^{22}$

Iolovitch fit right in. Of course, he chose his topic from the sector he knew best, the Jewish community. He explored principles and included intellectual and psychological concerns in his work. He filled On a Clear April Morning with discussions on the origins of anti-Semitism, the misguided paths mankind chooses, and the injustices of society but always beautified by his poetry and lightened by the ironies of Jewish humor.

In addition to Schopenhauer and Buber, Iolovitch and his friends read many of the nineteenth-century sages including Charles Darwin, 
Herbert Spencer, Auguste Comte, Ernst Haeckel, Ludwig Buchner, and Jean-Baptiste Lamarck. They were searching for a rational and scientific explanation of the cosmic and societal phenomena that surrounded them. They also read the moderns. Iolovitch listed among his favorites Erich Maria Remarque, Andre Gide, Aldous Huxley, Somerset Maugham, and Guillame Apollinaire. ${ }^{23}$

But it was probably Leo Tolstoy that most influenced On a Clear April Morning. In an interview at the time of this novel's first publication in 1940, Iolovitch notes that during the previous ten years he had been continually reading Tolstoy's early autobiographical novels, Childhood, Boyhood, and Youth. ${ }^{24}$ Iolovitch must have been inspired by Tolstoy's great powers of detailed pictorial observations that so mirrored his own. He must have felt a warm sense of companionship as he watched Tolstoy's protagonist, like Iolovitch himself and the protagonist he will create in On a Clear April Morning, struggle with ethical concerns, sexual awakening, and religious doubts.

Like Tolstoy, Iolovitch began his novel with a dateless moment: Iolovitch-"On a clear April morning in the year 19..."; Tolstoy-"On the $12^{\text {th }}$ of August, $18^{\star *} .{ }^{\prime 25}$ Both writers used these vague historical moments because these young authors, although drawing on their own experiences, sought to write universal tales of growing up. They sought to write tales filled with youth's desire to understand the world, to assess morality, and to find a path for a righteous and valued life. To create this universality, they didn't write autobiographies but used the autobiographical form that allows insertion of fictional elements and permits the author to choose "experiences which transform and mold a character." ${ }^{26}$

Tolstoy of course went on to write many more tales. Unfortunately, especially for those enthralled with On a Clear April Morning's beautiful prose, Iolovitch did not.

In the 1930s and 40s Iolovitch was a recognized member of the Gaucho literary world. His short stories and poems appeared in the prestigious Revista do Globo. When southern Brazilian literature was discussed, his name was included along with those whose fame still resonates today. $\mathrm{He}$ appears in numerous dictionaries of Brazilian and Latin American writers. He was interviewed on the front page of a major newspaper. ${ }^{27}$ The Brazilian pavilion at the 1939-40 World Fair in New York displayed his books. And Iolovitch formed part of Rio Grande do Sul's delegation to one of Brazil's most important cultural events of the twentieth century, the first Brazilian Writers Congress, held in São Paulo in $1945 .{ }^{28}$ But after the publication of Preces Profanas in 1949, his writing seems to have ceased. Instead, perhaps 
because of his new responsibilities as a father, he dedicated himself to his legal practice. He never made much money but then he didn't love the law. He had chosen legal studies because he needed to work his way through school and the law school didn't require class attendance, just successful final exams.

But just before Iolovitch ceased writing, a ten-year-old boy wrote him a letter extolling the beauty of Iolovitch's poems in Preces Profanas, "one of the most beautiful books I have ever read." ${ }^{29}$ That young boy grew up to be the noted author Moacyr Scliar who arranged for the second edition of Numa Clara Manha de Abril to be published in 1987 and passed the book to me. To Moacyr, the "god-father" of this English edition who I often felt guided its formation from on high (Moacyr passed away prematurely in 2011) I send my deepest gratitude. Because Moacyr believed so much in the inspirational beauty of Iolovitch's novel, English-language readers will now have their own chance to fall in love with On a Clear April Morning. 


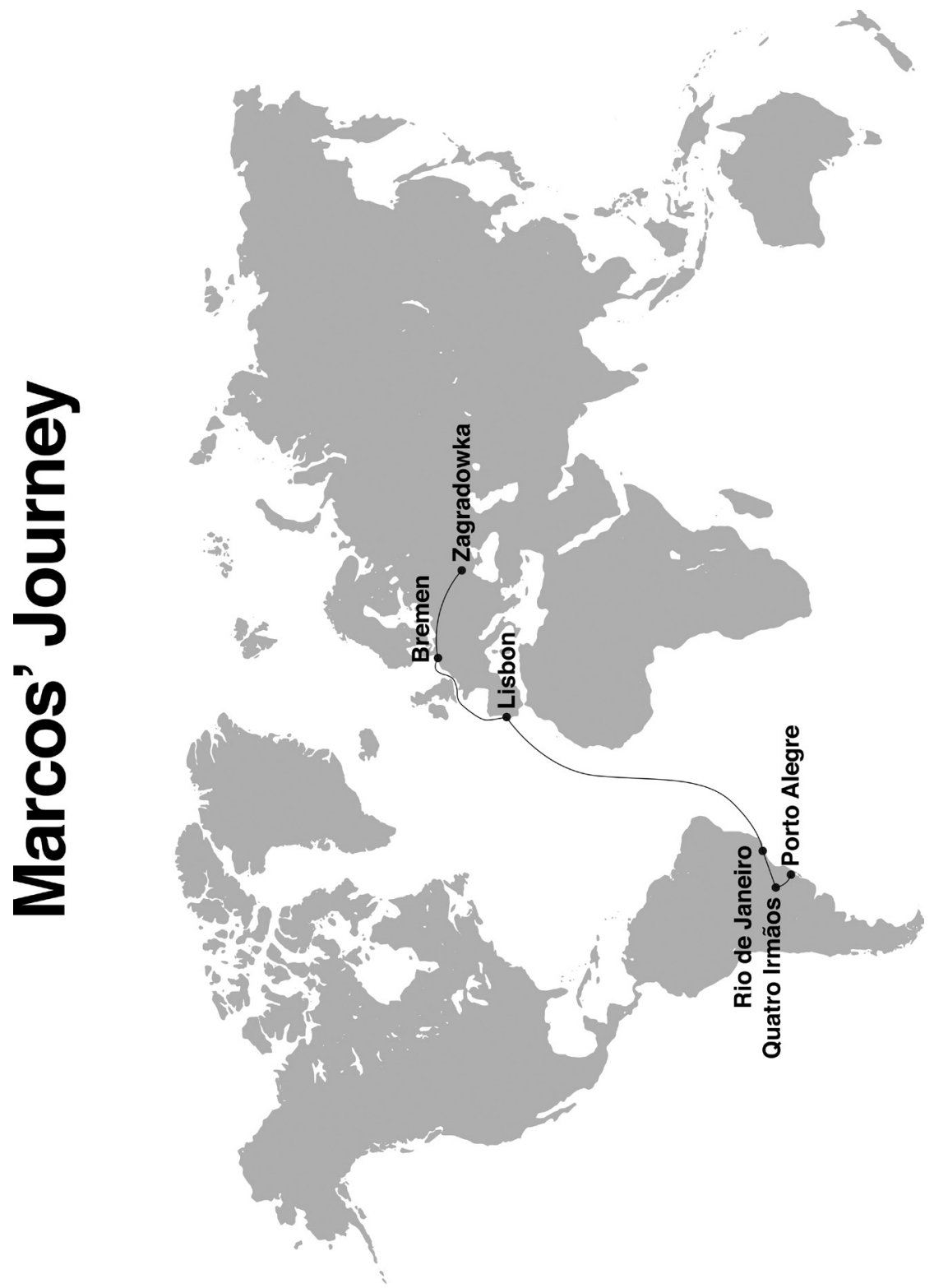

